\title{
IMPROVING STUDENTS' VOCABULARY MASTERY BY USING SONG LYRIC AT MTS NURUL YAQIN TONDANO \\ by Nur Ningsi
}

Submission date: 23-Jan-2021 03:58PM (UTC+0700)

Submission ID: 1492755217

File name: AP_NUR_NINGSI.docx (79.45K)

Word count: 3446

Character count: 17684 


\title{
IMPROVING STUDENTS' VOCABULARY MASTERY BY USING SONG LYRIC AT MTS NURUL YAQIN TONDANO
}

\author{
Nur Ningsi, Dra. Paula Rombepajung, M. Pd, Drs. Allowysius Rettob, M.Pd \\ English Education Department, Manado State University, Faculty of Language and Art, Manado State \\ University, Tondano, Indonesia \\ Email: ningsinur300@gmail.com
}

\begin{abstract}
This research aims at describing students' achievement of vocabulary mastery, and is conduct at MTsS Nurul Yaqin Tondano in the academic year 2019-2020. One class in the first grade is selected as the subject of the experiment. The clas 6 consists of 25 students. These students are the participants in this study. The writers use the pre-experimental design with one class pretest and post-test. It is quantitative research. The test or data collecting instrument to use in this researcl 17 a self-made vocabulary test in fill-in for 2 at. The result of computing the data analysis of mean score in pre-test and post-test there is a sig. pretest and posttest data are 3.1 and 4.9 respectively, and the stan 14 d deviations of pretest and posttest data are 1.3 and 1.2 respectively. It could conclude that the us 3 of song lyrics as a teaching technique improve student's vocabulary mastery is considering effective because it would create conducive and active learning condition which then motivate students to improve their vocabularies.
\end{abstract}

Keywords: Vocabulary Mastery, Song lyric.

\section{INTRODUCTION}

Although having long been introduced in foreign language teaching, music has just been more common use in English language teaching in recent years. The more frequent use of music particularly stems from the claims by theorists and pearchers in foreign language teaching that music and songs in the modern language classroom may provide positive emotional and learning enhancements for students at different ages and stages of learning (Spicher \& Sweeney, 2007 cited in
Ludke, 2009, p. 10). A similar claim atso comes from language teachers state that songs can quickly set a positive classroom tone (Jensen, 2000), improve foreign or second language (L2) intake in the learning process, and attract learners' attention to the linguistic material contained in the song.

Today, teacher's and students' attitudes towards the use of songs in second/foreign language classrooms change dramatically all over the world (Nisanci, 2013, p.1) as seen in their perceptions 
toward the use of songs in English classroon 20 Nguyen and Nguyen (2020) reveal that teachers have positive perceptions about songs using in vocabulary instruction $f_{6}$ young learners. Degrave (2019) finds a positive attitude of teachers towards the use of music in the foreign language classroom. Ranggen (2016) finds that the students and lecturers are agreed with the help of song in the learnitg process. Similarly, Hejjawi (2007) finds that most students in the study have positive attitudes toward the use of music in their language learning. Briefly, the previous studies revea ${ }_{6}$ that both teachers and students have a positive attitude toward the use of music and sorit in the languagelearning classroom. "Song is a very good 'tool' to help students learn English, more specifically songs are believed to be able to motivate students while following English learning" (Hampp, 2019).

Based on the above mention study, the writers try to using songs 21 teaching vocabulary. The purpose is to find out whether the use of songs in teaching vocabulary to students of MTsS Nurul Yaqin Tondano is effective as it has been revealing by the previous study.

\section{Statement of the Problem}

Based on the writers' experience in teaching at MTsS Nurul Yaqin Tondano her finding that most of the students are lack vocabulary. Therefore it is difficult for them to answer ask by the teacher in English.

\section{Research Question}

Based $15^{n}$ the previous research findings, the research question address in the present study is: is the use of pop songs increase students' memory retention of newlearn words?

2

\section{Purpose of the Study}

The present study aims to find out whether the use of pop songs increases students' memory retention of new-learn words. In other words, its aim to describe the effect of using songs on vocabulary learning.

\section{Significance of the Study}

The present study describes the effect of use music on vocabulary learning. The finding is of particular importance for English teachers in teaching vocabulary. They may use the finding to help their students increase their stock of vocabulary.

The finding can be used by other researchers ${ }_{2}$ the basis for conduct more studies on the effect of using songs on vocabulary learning.

\section{Scope and Delimitation}

The present study deals with the effect of songs on vocabulary learning. Vocabulary is too broad to be cover in a mini-research like this. Therefore, the researchers delimit their study to cover only 
unknown words or phrases in 'I have a dream', 'I see the light, and 'You are the reason'.

\section{Definitions of Key term}

A key term can be interpreted differently by many people. Therefore, to avoid misinterpretation, the following key terms should be clarified.

Vocabulary refers to a Total number of words, which (with rules for combining them) make up the language, or (2) (Range of) words known to or use by a person in trade, profession, etc. (Hornby, 1986:1462). In this study, vocabulary refers to unknown words or phrases in songs namely I have a dream, I See the Light, and You are the reason that is an experiment in this research. Therefore, they are also called 'new-learn words/phrase 8 '.

Music refers to an art of sound in time that expresses ideas and emotions in significant forms through the elements of rhythm, melody, harmony, and color" (http://dictionary ${ }_{9}$ eference.com/browse/mus ic?s=t), or the tones or sounds employed, occurring in single line (melody) or multiple lines (harmony), and sounded or to be sounded by one or more voices or instruments, or both."

Song refers to a sequence of syllables ('text') that is sung,

Lyric refers to a composed for singing (Oxford Dictionary, 1995: 703). In this study, lyrics refer to a set of words in $I$
Have a Dream, I See the Light, and You are the Reason that makes up this song.

\section{RESEARCH METHODOLOGY}

\section{Research Design}

The study is pre-experimental, in that, it tries to find out whether a causeeffect relationship exists between the independent variable, the use of songs, and the dependent variable, vocabulary mastery. Put it another way, the stud 24 attempts to obtain data concerning the effect of using songs on students' vocabulary mastery. The relationship between independent variables and dependent ones as visually is shown in Figure $3 \mathrm{~A}$.

\section{Independent \\ Using Songs}

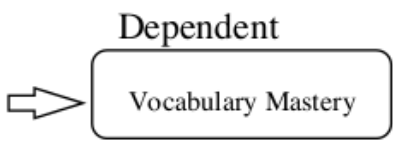

Figure 3A. Relationship between Independent - Dependent Variables

There are many $y_{26}$ pre-experimental designs. In this study, one group pretestposttest design is using. This design is selected because the researchers are allowing (by the school) to use only one class. The design is shown in figure $3 \mathrm{~B}$.

$$
\begin{array}{lll}
\mathrm{O}_{1} & \mathrm{X} & \mathrm{O}_{2}
\end{array}
$$

Figure 3B: One group pre-posttest design (Tuckman, 1999)

Where: 
$\mathrm{X}$ : Experimental Treatment

$\mathrm{O}_{\mathrm{I}} / \mathrm{O}_{2}$ : Observation (pretest) 1 and Observation (Posttest) 2

In terms of the nature of data and how it is analysis, the research falls into the category of quantitative research. It is quantitative in that the data is in the form of test scores, and analysis uses descriptive statistics.

The procedure research procedure is as follows:

1) Administer $\mathrm{O}_{1}$ the pre-test, to measure the mean of speaking test to the single group before exposure to the new teaching method

2) Expose subject to instructional material taught using songs $(\mathrm{X})$ for a given period;

3) Administer $\mathrm{O}_{2}$ or posttest to measure vocabulary mastery, and compare $\mathrm{O}_{1}$ and $\mathrm{O}_{2}$ to determine the effect of the experimental treatment on vocabulary mastery.

\section{Participants}

This study is conducting at in MTsS Nurul Yaqin Tondano in the academic year 2019-2020. One class in the first grade is selected as the subject of the experiment. The class consists of 25 students. These students are the participants in this study.

\section{Data Collection}

The test or data collecting instruments using in this research is a selfmade vocabulary test in fill-in format. The test consists of three excerpts from the song lyrics with 10 items each. After developing it, the test is valid to use expert judgment technique to see whether it is valid (see Yun \& Ulrich, 2002 in Aravamudhan \& Krishnaveni, 2015). The validation involves two English teachers at the MTsS having an English education background and an S1 degree. The validation is based on the criterion mention in Table 1 below.

Tabel 3B. Construct \& Content Validity Criteria

\begin{tabular}{|l|l|}
\hline $\begin{array}{l}\text { Presentasi Validasi } \\
13\end{array}$ & \multicolumn{1}{|c|}{ Criteria } \\
\hline $81 \%-100 \%(5)$ & Very high \\
\hline $61 \%-80 \% \quad(4)$ & High \\
\hline $41 \%-60 \% \quad(3)$ & $\begin{array}{l}\text { High } \\
\text { enough }\end{array}$ \\
\hline $21 \%-40 \% \quad(2)$ & Low \\
\hline $0 \%-20 \% \quad(1)$ & Very low \\
\hline
\end{tabular}

Results of experts' judgments indicate that the test's logical validity as high as shown in Table 2.

Table 3A. Construct \& content Validity Scoring

\begin{tabular}{|c|c|c|}
\hline Validator & Score & $\%$ \\
\hline Validator 1 & 4 & $75 \%$ \\
\hline
\end{tabular}




\begin{tabular}{|c|c|c|}
\hline Validator 2 & 4 & $80 \%$ \\
\hline Total & 8 & $77.5 \%$ \\
\hline
\end{tabular}

\section{Data Analysis}

The data is an analysis by using Descriptive Statistics, that is, by analyzing the frequency distribution, the mean and standard deviation scores of pretest and posttest standard deviation.

The frequency distribution score formula:

Total number of students got

$$
\text { a given score }
$$

Score $\%=$

Total number of students

The mean scores are computing using the mean formula:

$$
\bar{X}=\frac{\sum X}{n}
$$

(Butler, 1985:38)

Legend

$\mathrm{X}=$ Mean score

$\Sigma x=$ Total Number of student scores

$\mathrm{N}=$ Total number of student

Standard deviation is computing using the

\begin{tabular}{|c|c|c|c|c|c|}
\hline $\begin{array}{c}\text { Sc } \\
\text { or } \\
\mathrm{e}\end{array}$ & Tally & $\begin{array}{c}\text { Freq } \\
\text { uenc } \\
\mathrm{y}\end{array}$ & $\begin{array}{c}\text { Frequen } \\
\text { cy } \\
\text { Percenta } \\
\text { ge }\end{array}$ & $\begin{array}{c}\text { Cumulat } \\
\text { ive } \\
\text { Frequen } \\
\text { cy }\end{array}$ & $\begin{array}{c}\text { Cumulat } \\
\text { ive } \\
\text { Percenta } \\
\text { ge }\end{array}$ \\
\hline 5 & IIII & 4 & 16 & 25 & 100 \\
\hline 4 & IIIIII & 6 & 24 & 21 & 84 \\
\hline 3 & IIIII II & 7 & 28 & 15 & 60 \\
\hline 2 & IIIII & 5 & 20 & 8 & 32 \\
\hline 1 & III & 3 & 12 & 3 & 12 \\
\hline
\end{tabular}

raw score method

$$
\mathrm{S}=\frac{\sqrt{\sum \mathrm{x}^{2}}}{\mathrm{~N}}-(\bar{x})^{2}
$$

(Moore, 1983: 251)

Legend:

$\mathrm{s} \quad=$ standard deviation

$\sqrt{\sum \mathrm{x}^{2}}=$ sum square of $\mathrm{X}^{2}$

$\mathrm{n} \quad=$ number of student

$(\bar{x})^{2}=$ mean square

\section{FINDING AND DISCUSSION}

\section{Finding}

The data mention below are collecting twice, the pretest which is conduct at the MTsS on 19 September 2019, and the posttest, on 26 September 2019, use the same test, a 30 item fill-in-the-blank, is using. The data just mention are statistical analysis use descriptive statistics.

The analysis uses descriptive statistics to cover the calculation of frequency distribution, the mean and standard deviation of both groups of scores. Results of the analysis are then comparing to determine the effectiveness of use songs in teaching vocabulary.

23 Frequency Distribution of Pretest and Posttest data

Frequency distribution of both pretest and posttest data are calculating using the formula mention in 3.4. The result is present below. 


\section{Table 1. Frequency Distribution of Pretest Data}

As shown in Table 1, the highest score is 5, and the lowest 1 . Of 25 subjects who take the pretest, four or $16 \%$ get a five; six or $24 \%$ get a four; seven or $28 \%$ get a three; five or $20 \%$ get a two, and three or $12 \%$ get a one. Visually, the distribution of the pretest data is shown in Figure 1.

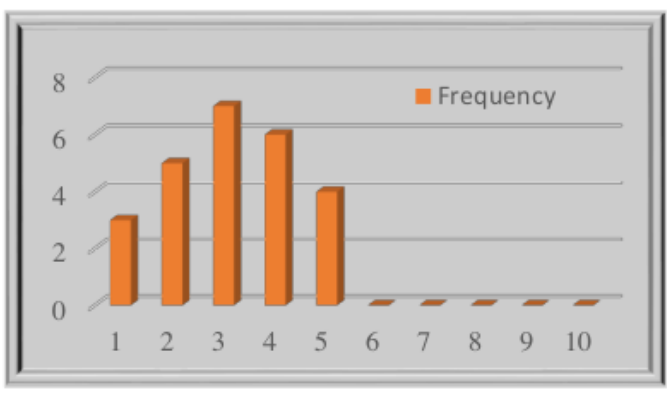

Figure 1. Frequency Distribution of Pretest Data

In the posttest, the same number of subjects is involving. The frequency distribution of posttest data, symbolize as Y, is present in Table 3 .

Table 3. Frequency Distribution of Posttest Data

\begin{tabular}{|c|c|c|c|c|c|}
\hline $\begin{array}{c}\text { Sc } \\
\text { ore }\end{array}$ & $\begin{array}{c}\text { Ta } \\
\text { lly }\end{array}$ & $\begin{array}{c}\text { Frequ } \\
\text { ency }\end{array}$ & $\begin{array}{c}\text { Frequ } \\
\text { ency } \\
\text { Percen } \\
\text { tage }\end{array}$ & $\begin{array}{c}\text { Cumul } \\
\text { ative } \\
\text { Freque } \\
\text { ncy }\end{array}$ & $\begin{array}{c}\text { Cumul } \\
\text { ative } \\
\text { Percen } \\
\text { tage }\end{array}$ \\
\hline 7 & $I I I$ & 3 & 12 & 25 & 100 \\
\hline 6 & $\begin{array}{r}I I I \\
I I\end{array}$ & 5 & 20 & 22 & 88 \\
\hline 5 & $\begin{array}{r}I I I \\
I I\end{array}$ & 7 & 28 & 17 & 68 \\
\hline
\end{tabular}

\begin{tabular}{|c|c|c|c|c|c|}
\hline & $I I$ & & & & \\
\hline 4 & $I I I$ & 6 & 24 & 10 & 40 \\
& $I I I$ & & & & \\
\hline 3 & $I I I$ & 4 & 16 & 4 & 16 \\
& $I$ & & & & \\
\hline
\end{tabular}

As shown in Table 3, the highest score is 7 and the lowest 3 . Of the 25 subjects who take the test, three or $12 \%$ get a seven; five or $20 \%$ get a six; seven or $28 \%$ get a five; six or $24 \%$ get a four, and four or $16 \%$ get a three. Visually, the distribution of posttest data is shown in Figure 2.

\begin{tabular}{|c|c|c|c|c|}
\hline No. & $\begin{array}{l}\text { Pretest } \\
\text { (X) }\end{array}$ & $\mathrm{X}^{2}$ & $\begin{array}{l}\text { Posttest } \\
\text { (Y) }\end{array}$ & $\mathrm{Y}^{2}$ \\
\hline 1 & 2 & 4 & 5 & 25 \\
\hline 2 & 3 & 9 & 7 & 49 \\
\hline 3 & 5 & 25 & 5 & 25 \\
\hline 4 & 3 & 9 & 6 & 36 \\
\hline 5 & 4 & 16 & 7 & 49 \\
\hline 6 & 3 & 9 & 5 & 25 \\
\hline 7 & 3 & 9 & 5 & 25 \\
\hline 8 & 4 & 16 & 6 & 36 \\
\hline 9 & 4 & 16 & 6 & 36 \\
\hline 10 & 2 & 4 & 4 & 16 \\
\hline 11 & 4 & 16 & 5 & 25 \\
\hline 12 & 2 & 4 & 4 & 16 \\
\hline 13 & 4 & 16 & 5 & 25 \\
\hline 14 & 5 & 25 & 7 & 49 \\
\hline 15 & 5 & 25 & 3 & 9 \\
\hline 16 & 3 & 9 & 5 & 25 \\
\hline 17 & 1 & 1 & 3 & 9 \\
\hline 18 & 5 & 25 & 4 & 16 \\
\hline 19 & 2 & 4 & 4 & 16 \\
\hline 20 & 4 & 16 & 6 & 36 \\
\hline 21 & 1 & 1 & 3 & 9 \\
\hline 22 & 3 & 9 & 4 & 16 \\
\hline 23 & 3 & 9 & 6 & 36 \\
\hline 24 & 1 & 1 & 3 & 9 \\
\hline 25 & 2 & 4 & 4 & 16 \\
\hline $\begin{array}{c}\mathrm{N} \\
= \\
25\end{array}$ & $\sum X=78$ & $\begin{array}{c}\sum \mathrm{X}^{2}= \\
282\end{array}$ & $\sum Y=122$ & $\begin{array}{c}\sum \mathrm{Y}^{2}= \\
634\end{array}$ \\
\hline
\end{tabular}




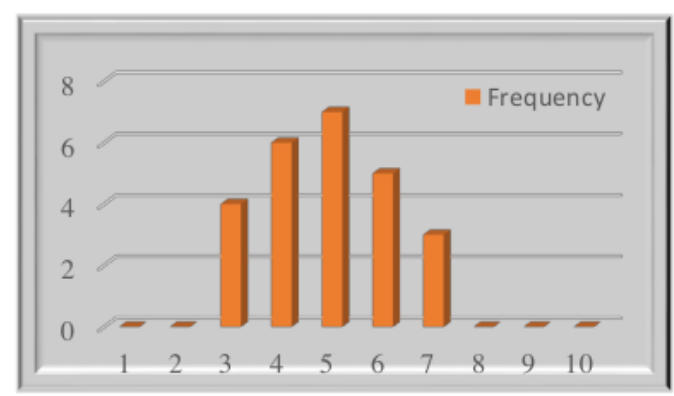

Figure 2. Frequency Distribution of Posttest Data

\section{Calculation of Mean and Standard Deviation}

To know the mean and standard deviations of both pretest and posttest data, it is important to first find the sums and sum squares of the groups of data.

\section{Table 4. Sums and Sum Squares of $X$ and $Y$}

Based on the sums of $\mathrm{X}$ and $\mathrm{Y}$ as shown in Table 4, the mean of pretest and posttest data are calculated.

$$
\begin{aligned}
& \bar{X}=\frac{78}{25}=3.1 \\
& \mathrm{Y}=\frac{122}{25}=4.9
\end{aligned}
$$

Also based on the sum squares of $\mathrm{X}$ and $\mathrm{Y}$ depicted in Table 4, standard deviations of the two groups of data are calculated as shown below.

$$
\begin{aligned}
& \mathrm{s}_{\mathrm{x}}=\sqrt{\frac{282}{25}}-3.1^{2}=\sqrt{11.3}-9.6 \\
& =\sqrt{1.7}=1.3
\end{aligned}
$$

$$
\begin{aligned}
\mathrm{Sy} & =\sqrt{\frac{634}{25}}-4.9^{2}=\sqrt{25.4}- \\
24.01 & =\mathrm{s} \sqrt{1.39}=1.2
\end{aligned}
$$

To sum up, the result of the data analysi $\$_{15}$ in which frequency distribution, the mean and standard deviations of both pretest and $\mathrm{p}_{25}$ test data are calculating, show that (1) the highest score is 5 and the lowest 1 ; the highest score is 7 and the lowest 3; (2) the means of pretest and posttest data are 3.1 and 4.9 respectively; and the standard deviations of pretest and posttest data are 1.3 and 1.2 respectively. These three statistics indicate that the subjects' performances after being expos to the treatment, vocabulary taught use songs, increase compare to their performance before the treatment. Put it another way, teaching vocabulary using songs effectively increase students' memory retention of new-learn words.

\section{Discussion}

The present study tries to answer the research question: Is the use of pop songs effective increase students' memory retention of new-learn words? Results of calculation of frequency distribution, the mean and standard deviation indicate that there is an increase in the subjects' vocabulary performance after being expos to the teaching of vocabulary using songs. For example, the highest and low scores before the treatment are 5 and 1 ; in the posttest administer after the treatment, the 
highest score is 7 and the low 3 ; the mean after the treatment increases almost 2 points, and that the subjects' heterogeneous performances $(s=1.3)$ before the treatment decreases to 1.2. These results lead to the conclusion that use songs in teaching vocabulary increases the subjects' memory retention of new-learn words.

This find goes in line with the find of the previous study. Malekian (2016) who aims at describing the relationship between English son 5 and learning vocabulary finds that songs provide an enjoyable way to introduce or review vocabulary, teach pronunciation, present structures, and sentence patterns in a novel way. It's an innovative and efficient method to use English songs to improve students' listening and speaking a $a_{14}$. Ningsih (2019), who aims at findings the effectiveness of using songs in teaching $\mathrm{E}_{16}$ lish at Sulawesi flight college, finds that there is a significant difference in students' English achievement before and after being taught by uring songs. Gushendra (2017), who tries to find out a significant effect of using English songs to improve st12 ${ }^{2}$ nts' vocabulary mastery, reveals that use English songs can improve the students' vocabulary mastery. Si 2 ilarly, Phisutthangkoon (2016), who tries (a) to study the effectiveness of song activities on vocabulary learning and retention and (b) to explore stude $_{2}$ 's' opinions towards song activities, find that there is a significant difference between the pretest and posttest I mean scores of the students' English ${ }_{18}$ ocabulary achievement at a level .01 and that students have positive attitudes toward use song activities to develop their vocabulary learning and retention. Briefly, the previous find that using songs is not only increases students' vocabulary but also their motivation to learn.

Both the present study and the previous ones support the claim by theorists, researchers, and language teachers that music and songs in the modern language classroom may provide positive emotional and learning enhancements for students at different ages and stages of learning (Spicher \& Sweeney, 2007 cited in Ludke, 2009, p. 10). A similar claim elso comes from language teachers stating that songs can quickly set a positive classroom tone (Jensen, 2000), improve foreign or second language (L2) intake in the learning process, and attract learners' attention to the linguistic material contained in the song. In the fields of psychology and neuroscience, research finds indicate that for example, revealing that music has been shown to support verbal learning in the native language (Thaut et al, 2008). These finds confirm Krashen's affective filter theories the learning a second/foreign is effective if an affective filter is low and ineffective if it is high. 


\section{CONCLUSION AND SUGGESTION}

\section{Conclusion}

The present study tries to answer the research question: Is the use of pop songs effectively increase students' memory retention of new-learn words? Results of calculation of frequency distribution, the mean and standard deviation indicate that there is an increase in the subjects' vocabulary performance after being expos to the teaching of vocabulary use songs. These results lead to the conclusion that use songs in teaching vocabulary increases the subjects' memory retention of new-learn words.

\section{Suggestions}

Based on the conclusion above, the writers would like to suggest English teachers to using song lyric techniques in teachigg vocabulary for students not only the senior high school students, but also junior high school and elementary school to attract the students' attention, interest, and motivation in learning English.

Teachers or prospective teachers have to know that this is one of many techniques suitable apply when teaching English in the classroom to make it easy for students to understand the mater ${ }_{3}$ l. Therefore, they are suggesting using this technique when teaching English as a foreign language in improving students' mastery of vocabulary.

\section{REFERENCES}

Ahmadi, Khoiru, Lif. Dkk. (2011). Strategi Pembelajaran Sekolah Terpadu. Jakarta: Prestasi Pustaka.

As. Hornby. (1986). Oxford Advanced Learners' Dictionary of Current English. England.

Degrave, Pauline. (2019). Music in the Foreign Language Classroom: How and Why? UCLouvain, Belgium Journal of Language Teaching and Research, Vol. 10, No. 3, pp. 412-420, May 2019 DOI:

http://dx.doi.org/10.17507/jltr.1003 .02 .

Finocchiaro, M, \& M. Bonomo. (1973). the Foreign Language Learner A Guide For Teacher. New York: Regent Publishing Company, Inc.

Gushendra, Rizky. (2017). The Improving Students Vocabulary Mastery by Using English Song at SMPN 1 Kampang Timur.

Hejjawi, K. Linna. (2007). Teachers' and Students' Attitudes Toward the use Of Music in Use English Language Classrooms. American University of Sharjah.

(http://dictionary .reference.com/browse/mus ic? $\mathrm{s}=\mathrm{t}$

Iin, Susanti, Evi. (2012). Improving Students' Vocabulary by Using 
Song and Game. At the: SD

Kristen Kanaan Sungai Raya Dalam.

Jensen, E. (2000). Music with The Brain In Mind: Enhance Learning With Music. San Diego, California: Corwin Press.

Kridalaksana, Harimurti. (2008). Kamus Linguistik Jakarta: PT Gramedia Pustaka Utama.

Malekian, Sahar. (2016). the Relationship between English Songs and Learning Vocabulary. International Journal of African and Asian Studies, ISSN 2409-6938, An International Peer-reviewed Journal Vol.20, 2016. www.iiste.org.

Masri, Sulaiman. Dkk. (2007). Manajemen Pendidikan. Bandung: ROSDA

Murphey, T. (1990). The Song Stuck in My Head phenomenon: A melodic din in the LAD? System, 18(1): 53-64.

Nisanci, Ibrahim. (2013). Using Authentic Songs to Teach English: An Analysis of Students' Perceptions. Dicle University.

Nguyen, T, Cam. \& Nguyen, Buu, Huan. (2020). Teachers' Perceptions about Using Songs in Vocabulary Instruction to Young Language Learners. Aston English Language Center, Vietnam School of Foreign Languages, Can Tho University, Vietnam. Universal Journal of Educational Research 8(6): 2678-
2685, $2020 \quad$ DOI:

10.13189/ujer.2020.080652, http://www.hrpub.org.ss

Nurgiyantoro, Burhan. (2001:213). Penilaian Dalam Pengajaran Bahasa \& Sastra. Edisi ketiga. Cet. Pertama. Yogyakarta: BPFE.

Ranggen, R, Bagas. (2016). Students' Perceptions on the Support of English Songs to Students' English Developments. Sanata Dharma University Yogyakarta.

Phisutthangkoon, Kittiya. (2016). Effectiveness of English Song Activities on Vocabulary Learning and Retention. Rajamangala University of Technology Srivijaya, Thailand Metas Panich.

Schön, D., Boyer, M., Moreno, S., Besson, M., Peretz, I. \& Kolinsky, R. (2008). Songs as an aid for language acquisition. Cognition, 106(2): 975-983.

Scoot, Calum. Maguire Jon, \&Sanders, J. Corey. (8 -1 - 2018). You Are The Reason. British.

Spicher, L. \& Sweeney, F. (2007). Folk music in the L2 classroom: Development of native like pronunciation through prosodic engagement strategies. Connections, 1: 35-48.

Tuckman, W. Bruce. (1999). Conducting Educational Research. Harcourt Brace College Publishers. 
Wallace, J. Michael. Guiford, \& K. Lynn. (1982). Teaching Vocabulary. London: Bridles ltd.

Yun J., Ulrich, D. (2002) Estimating measurements validity: A tutorial. Adapted Physical Activity Quarterly, 19, pp. 32-47. 


\section{IMPROVING STUDENTS' VOCABULARY MASTERY BY USING SONG LYRIC AT MTS NURUL YAQIN TONDANO}

ORIGINALITY REPORT

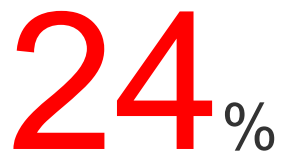

SIMILARITY INDEX

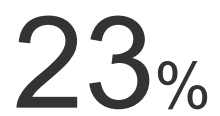

INTERNET SOURCES
$8 \%$

PUBLICATIONS
$12 \%$

STUDENT PAPERS

PRIMARY SOURCES

1 www.researchgate.net

Internet Source

2 papers.iafor.org

Internet Source

3 documents.mx

Internet Source

4 repository.uinjkt.ac.id Internet Source

5 www.mjal.org

Internet Source

6 academypublication.com

Internet Source

7 ejournal.unima.ac.id Internet Source

8 WwW.worldscientificnews.com Internet Source 
10 dspace.aus.edu:8443

Internet Source

11 Submitted to Universitas Negeri Manado

Student Paper

12 123dok.com

Internet Source

13 cis.uws.ac.uk

Internet Source

14 eprints.walisongo.ac.id

Internet Source

15 www.academypublication.com

Internet Source

16 Submitted to Universitas Muria Kudus

Student Paper

17 eprints.iain-surakarta.ac.id

Internet Source

18 Submitted to University of Exeter

Student Paper 
21 Submitted to Victoria University

Student Paper

22 researcharchive.vuw.ac.nz

Internet Source

23 Gustavo Zurita. "A conceptual framework based on Activity Theory for mobile CSCL", British Journal of Educational Technology, 3/2007

Publication

24 umppbi.com

Internet Source

25 Lia Aris Tantya, Syaifudin Latif Darmawan.

"THE INFLUENCE OF USING THINK PAIR

SHARE AND PAIRS CHECK TEHNIQUE

TOWARD STUDENTS' WRITING ABILITY IN

RECOUNT TEXT AT THE STUDENTS OF SMP

$N 2$ PEKALONGAN ACADEMIC YEAR

2013/2014", PREMISE JOURNAL:ISSN online:

2442-482x, ISSN printed: 2089-3345, 2017

Publication

26

Singleton, Royce A.. "Approaches to Social

Research", Oxford University Press

Publication 
